\title{
Quality of life of children with poor school performance: association with hearing abilities and behavioral issues
}

\author{
Qualidade de vida de crianças com mau desempenho escolar: associação com as \\ habilidades auditivas e aspectos comportamentais
}

Bárbara Antunes Rezende1, Stela Maris Aguiar Lemos², Adriane Mesquita de Medeiros²

\begin{abstract}
The aim of the present study was to investigate the quality of life of children with poor school performance and its association with behavioral aspects and hearing abilities. Methods: This cross-sectional observational study, developed in a town in the state of Minas Gerais, Brazil, investigated a random sample of public school children, aged 7-12 years old, who performed poorly in school and received specialized educational assistance. The study comprised two stages: 1) collection of data from parents on their children's health, educational, and socioeconomic profile, and from the Strengths and Difficulties Questionnaire; 2) administration of a quality of life evaluation scale to the schoolchildren. For the assessment of auditory function, transient otoacoustic emissions were used and auditory processing was tested. The following tests were used: verbal sequential memory, nonverbal sequential memory, sound localization, dichotic digits, duration pattern test (flute) and random gap detection. The collected data were analyzed using Excel and STATA 11.0 software. Quality of life was considered the response variable. The explanatory variables were grouped for univariate and multivariate logistic regression analysis with the level of significance set at $5 \%$. Results: A statistically significant association was found between impaired quality of life, altered pro-social behavior, and the absence of parental complaints about the children's written language development. Conclusions: Quality of life is impaired in children with poor school performance. The lack of parental complaints about written language and changes in social behavior increased the likelihood of a child having a poor quality of life.
\end{abstract}

Keywords: Quality of life; underachievement; child behavior; hearing tests; child

\section{RESUMO}

Investigar a qualidade de vida de crianças de 7 a 12 anos de idade com mau desempenho escolar e a associação com as características comportamentais e habilidades auditivas. Métodos: Estudo observacional transversal realizado com crianças de 7 a 12 anos de idade, com mau desempenho escolar das escolas públicas municipais de uma cidade do interior de Minas Gerais, Brasil, participantes de atendimentos educacionais especializados. Etapas: 1) coleta de informações com os pais sobre a saúde, perfil escolar e socioeconômico e preenchimento do Strengths and Difficulties Questionnaire; 2) etapa com as crianças para aplicação da Escala de Avaliação da Qualidade de Vida. Para a avaliação da função auditiva foram utilizadas as Emissões Otoacústicas Transientes e a avaliação do processamento auditivo, sendo os testes aplicados: teste de memória de sons verbais em sequência, teste de memória de sons não verbais em sequência, localização sonora, teste dicótico de dígitos, teste de padrão de duração (flauta) e Random Gap Detection. Os dados coletados foram analisados por meio dos programas Excel e STATA 11.0. Foi considerada como variável resposta a qualidade de vida e as variáveis explicativas foram agrupadas para análise de regressão logística uni e multivariada, considerando o nível de significância de 5\%. Resultados: Foi encontrada associação estatística entre qualidade de vida prejudicada, comportamento pró-social alterado e ausência de queixa parental de linguagem escrita. Conclusão: A qualidade de vida está comprometida nas crianças com mau desempenho escolar. A ausência de queixa sobre o desenvolvimento da linguagem escrita e comportamento pró-social alterado aumentaram a chance de a criança apresentar qualidade de vida prejudicada.

Palavras-chave: Qualidade de vida; baixo rendimento escolar; comportamento infantil; testes auditivos; criança.

Learning is a process that occurs through the integration of various functions of the nervous system, improving the adaptation of the individual to the environment. The interaction between the individual and the environment occurs through experience during the process of learning, resulting in changes ${ }^{1}$.

\footnotetext{
1 Universidade Federal de Minas Gerais, Pós-Graduação em Saúde Pública, Belo Horizonte MG, Brasil;

${ }^{2}$ Universidade Federal de Minas Gerais, Departamento de Fonoaudiologia, Belo Horizonte MG, Brasil.

Correspondence: Bárbara Antunes Rezende; Universidade Federal de Minas Gerais; Avenida Alfredo Balena, 190 / sala 249; 30130 -100 Belo Horizonte MG, Brasil; E-mail: barbararezende87@gmail.com

Bárbara Antunes Rezende (iD) https://orcid.org/0000-0002-5046-1716

Conflict of interest: There is no conflict of interest to declare.

Received 08 March 2018; Received in final form 30 September 2018; Accepted 31 October 2018.
} 
The term "learning disorder" should not be used as a synonym for learning difficulties. "Difficulty" is a more comprehensive and inclusive term, with causes related to the person learning, the educational content, the teacher, the teaching methods and even the physical and social environment of the school; whereas a learning disorder refers to a group of more specific difficulties, characterized by the presence of a neurological disorder that is responsible for the failure in writing, reading, and/or mathematics ${ }^{2}$.

Poor school performance can be defined as an educational achievement below the expected for a given age, cognitive skills and schooling. Poor school performance must be viewed as a symptom related to various etiologies and it can result in emotional problems and family concerns ${ }^{3}$.

Quality of life has been increasingly investigated in the health field with publications about evolution and therapy in various situations ${ }^{4}$. The World Health Organization defines quality of life as the "individual's perception of their position in life in the context of the culture and value systems in which they live and in relation to their goals, expectations, standards and concerns" 5 .

The development and use of quality-of-life measurements in Pediatrics has increased dramatically, in an effort to assess the health and welfare of individuals in its totality. This concern for quality of life also begins to appear in school students.

However, research has shown that the perceptions of parents and medical staff in contact with children under evaluation usually have low levels of correlation with the child's self-assessment ${ }^{6}$.

It is believed that children with poor school performance may have their quality of life negatively affected by several factors, such as impaired hearing abilities and behavioral issues.

An auditory processing disorder occurs when a factor adversely affects or disrupts the interpretation of sound information. When this happens, the person may be impaired in the acquisition and development of language ${ }^{7}$. The association between the alteration in auditory processing and reading difficulties, such as in dyslexia, has already been demonstrated in literature ${ }^{8,9}$.

Just like an auditory processing disorder, a learning disability is almost always found in association with other impairments. Studies have shown that children with learning difficulties commonly manifest emotional and behavioral problems in parallel ${ }^{10,11}$.

In view of this, the aim of this study was to investigate the quality of life of children with poor school performance and the association with behavioral characteristics and hearing abilities.

\section{METHODS}

This was a cross sectional observational study in a small city with a probability sample of children, aged 7-12 years, who were public school students with poor school performance and participants in the Specialized Educational Assistance program ${ }^{11}$.

The students and their legal guardians were invited to participate in the research and those who agreed were oriented on all the procedures of the study and signed the informed consent form about the purpose, importance, confidentiality, risks and benefits of the research. Inclusion criteria for the study were: children whose ages were in accordance with the research proposal (7-12 years); children who, with their parents, signed the informed consent form; children who were enrolled and attending a municipal school as well as the Specialized Educational Assistance program. Children who did not undergo all evaluations proposed or had incomplete questionnaires; or with evidence or history of neurological, cognitive and/or psychiatric disorders, were not included in the research sample.

Sample size was estimated in view of prevalence studies and association between outcome and independent variables. The calculation considered 9\% sampling error, 95\% confidence interval and $50 \%$ prevalence, considering the range of outcomes of interest. Taking into account the criteria presented, a sample of 90 children was estimated.

The data collection was conducted and divided into two parts. The first stage was carried out with the parents, in order for the questionnaires to be applied. The questionnaire for parents/legal guardians comprised sociodemographic, health aspects and school life questions. In addition, the socio-economic profile was determined (Critério de Classificação Econômica Brasil) ${ }^{12}$. Afterwards, the parents were instructed on how to complete the Strengths and Difficulties Questionnaire (SDQ) ${ }^{13}$. The results were analyzed according to the criteria proposed by the author. Moreover, the questionnaire was read to illiterate parents, thus aiding them in selecting the answers.

The second stage of the application of the quality of life questionnaire and hearing evaluation was carried out with the children. The children answered the questionnaire Autoquestionnaire Qualité de Vie Enfant Imagé (AUQEI) ${ }^{6}$ and rated their self-perceived health. The questionnaire is based on the viewpoint of the child's satisfaction using pictures (faces expressing different emotional states) that are associated with various domains, by means of 26 questions that explore family, social relationships, school activities and health. Without a specific time frame, the child was asked to mark the answer that best corresponded to his or her feeling in relation to the proposed domain. Initially, however, the child was asked to describe a prior experience that related to each answer. The researcher read the sentences and asked the child to point to the face that expressed the feeling that such situation brought. After answering the questionnaire, the child was questioned about his or her general health, with the same alternatives given to the parents: "In general, would you say your health is: excellent, good, fair, bad or very bad”. 
Next, the researcher performed the audiological and central auditory processing evaluation of the child. To verify hearing acuity, the inspection of the external ear canal was performed first and, subsequently, transient otoacoustic emissions, which detect the integrity of cochlear function and allow for the exclusion of middle ear disorders. The participants who failed a test, were referred for audiological/otorhinolaryngological evaluation. The Mini Heine 3000 was used to perform the inspection of the external auditory meatus. The equipment used to test the otoacoustic emissions was the OtoRead - Standard and Clinical Interacoustics, version 7.65.01.

The children who passed the transient otoacoustic emissions underwent the following auditory processing tests: verbal sequential memory test, nonverbal sequential memory test, sound localization test, dichotic digit test, duration pattern test (flute) and random gap detection test. The evaluation criteria adopted were those suggested by Pereira et al. ${ }^{14}$ and Amaral et al. ${ }^{15}$. If the child showed any difficulty in understanding one of the tests, even after training, the assessment was not completed, and the data of the respective test was not analyzed. The equipment used to perform the assessment of auditory processing was the Acústica Orlandi two-channel audiometer PAC-2000 and TDH-39 (ANSI standard, 1969) headphones coupled to the Philips Micro System AZ1050.

In order to assess sound pressure levels in the evaluation room, the Instrutherm DEC-490 sound pressure level meter was utilized. The equipment was calibrated within the period of validity. Measurements were performed in accordance with procedures stated by the Brazilian standard regulation NBR $10.151^{16}$. The average noise level was $50 \mathrm{~dB}(\mathrm{~A})$, in accordance with the recommended range, which states that the noise in classrooms should vary between $40 \mathrm{~dB}(\mathrm{~A})$ and $50 \mathrm{~dB}(\mathrm{~A})^{17}$.

After collecting the data, the results of the instrument examinations were organized, scanned into a database, and checked. A descriptive analysis of the frequency distribution of categorical variables and the analysis of measures of central tendency and dispersion for continuous variables were performed. The collected data were digitized and analyzed with Excel and STATA 11.0 software.

The response variable considered was quality of life. The dichotomized variable was proposed in the study by
Assumpção Junior et al. ${ }^{6}$, in which quality of life was related as "not affected" or "affected". The child answers 26 questions with the sum of the items presented as a total score. For each answer, the child would score as follows: very unhappy $=0$; unhappy $=1$; happy $=2$; very happy $=3$. The minimum score established for the study was 48 points. In other words, those children with a total score lower than 48 points were classified as having an affected quality of life.

Explanatory variables were grouped in order to organize a hierarchical model of analysis (Table 1). The more distal variables correspond to the ones in the first block; the more proximal variables can be found in the last block.

In the first stage, the univariate logistic regression analysis was performed. It considered the explanatory variables in each block with a $5 \%$ level of significance. In the second stage, all variables associated with quality of life that showed a p-value $\leq 0.20$ in the univariate analysis were included in the multivariable models, considering the variables belonging to the same block only. The procedure of sequential deletion of variables starting from the most distal variables within each block was used, leaving in the final model, only variables associated with quality of life in terms of a p-value $\leq 0.05$.

The magnitude of association was measured by the odds ratio with confidence intervals. A $95 \%$ confidence interval was obtained.

This project was reviewed and approved by the ethics committee, number 403.08/UFMG.

\section{RESULTS}

The average score in the AUQEI of the 99 children evaluated was 50.37 points, the minimum score being 34 points, and the maximum score 69 points. All the children who participated in the survey attended the Specialized Educational Assistance program in the school environment, and $45.5 \%$ of the students also received care at the Center for Integral Assistance to Children.

An affected quality of life was reported by $36.4 \%$ of the surveyed children. In this group, the majority of participants were male (64\%), aged between seven and eight years old (47\%), and their mothers were illiterate or had primary education

Table 1. Variables for entry into the hierarchical model of multivariate analysis.

\begin{tabular}{|c|c|c|}
\hline 1st Block & $\begin{array}{l}\text { Sociodemographic } \\
\text { characteristics: }\end{array}$ & Gender, age, child's schooling, maternal education and economic classification. \\
\hline 2nd Block & Health aspects & $\begin{array}{c}\text { Medical diagnosis, gestational age, postpartum complications, breastfeeding, } \\
\text { prescription drugs. }\end{array}$ \\
\hline 3rd Block & $\begin{array}{l}\text { Assessment of auditory } \\
\text { processing }\end{array}$ & $\begin{array}{l}\text { Nonverbal sequential memory test, verbal sequential memory test, sound localization } \\
\text { test, duration pattern test (flute), random gap detection test and dichotic digits test. }\end{array}$ \\
\hline 4th Block & $\begin{array}{l}\text { Behavioral aspects, } \\
\text { self-reported health status } \\
\text { and school life }\end{array}$ & $\begin{array}{l}\text { Emotional symptoms, conduct problems, hyperactivity symptoms/signs, problems with } \\
\text { classmates, pro-social behavior, flunking, school enjoyment, total SDQ score, impact } \\
\text { supplement of SDQ, parental report about children's health status, self-reported health } \\
\text { status, parental complaints about written language. }\end{array}$ \\
\hline
\end{tabular}


only (60\%) and belonged to economy class C - medium/low (64\%). Most children (80.6\%) had no medical diagnosis at the time of the evaluations, only the reported complaint of poor school performance, nor did they use prescription medication (75\%). Regarding neonatal conditions, most of the schoolchildren were full-term (97\%) without postpartum complications (88.6\%) and were exposed to breastfeeding (86\%). In the univariate analysis, none of the variables related to the general characteristics of children was statistically associated with the worst quality of life (Table 2).

Table 3 shows data concerning the auditory processing tests. It was verified that the children with the greatest impairment in quality of life were those who presented with alterations in the tests that evaluated temporal aspects of hearing. In the duration pattern test (flute), which assesses the complex temporal ordering auditory ability, $56 \%$ of the children presented with an altered test and affected quality of life. In the random gap detection test, $80.7 \%$ of children with a temporal resolution inadequacy had worse quality of life indications. In the univariate analysis, none of the variables related to auditory processing tests was statistically associated with affected quality of life.

Regarding the behavioral aspects, self-perceived health and school life (Table 4), it was observed that $68 \%$ of the sample showed altered results on the Strengths and Difficulties Questionnaire, i.e., the total score of the difficulties indicated clinical behavioral issues in these children. Furthermore, the impact supplement of the Strengths and Difficulties Questionnaire showed that $77 \%$ of the students who had difficulties in other activities (leisure, friendships, learning) also had a negative impact on their quality of life. As for the Strengths and Difficulties Questionnaire subscales, it was found that most children with an affected quality of life showed alterations in emotional symptoms (77\%), relationship problems (67\%), as well as behavioral problems and hyperactivity signs (61\%). In the univariate analysis, the association between quality of life and pro-social behavior showed a value close to the level of significance $(p=0.056)$.

Table 2. Descriptive analysis and univariate association between quality of life, sociodemographic profile and child's health.

\begin{tabular}{|c|c|c|c|c|}
\hline Variable & Not impaired n (\%) & Impaired n (\%) & Odds Ratio $(95 \% \mathrm{Cl} *)$ & $\mathrm{p}$-value \\
\hline \multicolumn{5}{|l|}{ Age } \\
\hline 07/ago & $36(57.1)$ & $17(47.2)$ & 1 & \\
\hline 09/out & $17(27.0)$ & $12(33.3)$ & $1.49(0.58-3.83)$ & 0.40 \\
\hline 11/dez & $10(15.9)$ & $7(19.4)$ & $1.48(0.47-4.59)$ & 0.49 \\
\hline \multicolumn{5}{|l|}{ Gender } \\
\hline Male & $43(73.0)$ & $23(64.0)$ & 1 & \\
\hline Female & $17(27.0)$ & $13(36.0)$ & $1.52(0.63-3.69)$ & 0.34 \\
\hline \multicolumn{5}{|l|}{ Child's schooling } \\
\hline $1-3$ years & $41(65.1)$ & $22(61.0)$ & 1 & \\
\hline 4 years & $13(20.6)$ & $9(25.0)$ & $1.29(0.47-3.50)$ & 0.62 \\
\hline $5-6$ years & $9(14.3)$ & $5(14.0)$ & $1.03(0.30-3.49)$ & 0.95 \\
\hline \multicolumn{5}{|l|}{ Maternal education } \\
\hline Illiterate /Elementary school & $38(64.4)$ & $21(60.0)$ & 1 & \\
\hline Secondary school/Higher education & $21(35.6)$ & $14(40.0)$ & $1.20(0.50-2.86)$ & 0.67 \\
\hline \multicolumn{5}{|l|}{ Economic classification } \\
\hline B & $14(23.3)$ & $5(13.9)$ & 1 & \\
\hline C & $41(68.4)$ & $23(63.9)$ & $1.57(0.49-4.94)$ & 0.44 \\
\hline $\mathrm{D}$ & $5(8.3)$ & $8(22.2)$ & $4.48(0.97-20.51)$ & 0.05 \\
\hline \multicolumn{5}{|l|}{ Medical diagnosis } \\
\hline Yes & $7(11.1)$ & $7(19.4)$ & 1 & \\
\hline No & $56(88.9)$ & $29(80.6)$ & $0.51(0.16-1.62)$ & 0.26 \\
\hline \multicolumn{5}{|l|}{ Gestational age } \\
\hline Full-term & $54(90.0)$ & $34(97.1)$ & 1 & \\
\hline Premature & $6(10.0)$ & $1(2.9)$ & $0.26(0.30-2.32)$ & 0.23 \\
\hline \multicolumn{5}{|l|}{ Postpartum complications } \\
\hline Yes & $15(25.0)$ & $4(11.4)$ & 1 & \\
\hline No & $45(75.0)$ & $31(88.6)$ & $2.58(0.77-8.58)$ & 0.12 \\
\hline \multicolumn{5}{|l|}{ Breastfeeding } \\
\hline Yes & $54(88.5)$ & $31(86.1)$ & 1 & \\
\hline No & $7(11.5)$ & 5 (13.9) & $1.24(0.36-4.28)$ & 0.73 \\
\hline \multicolumn{5}{|l|}{ Prescription drug use } \\
\hline Yes & $15(24.1)$ & $9(25.0)$ & 1 & \\
\hline No & $47(75.9)$ & $27(75.0)$ & $0.95(0.36-2.49)$ & 0.93 \\
\hline
\end{tabular}


Considering the information about school life, most of the children who failed at school (23\%) had an affected quality of life (34\%). In addition, the students who had the worst quality of life (42\%) were those whose parents who, during the assessment, answered that the child did not show difficulties regarding written language. Conversely, most of these children related that they liked going to school (53\%). In the univariate analysis, it was observed that flunking was the only variable that presented statistical significance with quality of life $(p=0.05)$ (Table 3$)$.

The eligible variables for the multivariate model $(p \leq 0.20)$ were economic classification (block 1), postpartum complications (block 2), verbal sequential memory (block 3), selfreported health, emotional symptoms, school enjoyment, relationship problems, parental complaints about written language, pro-social behavior, and flunking (block 4).

Table 5 shows the final model of the multivariate analysis with the variables that maintained the $5 \%$ level of significance. There was a positive association between the lack of complaints from parents or legal guardians about written language, and altered pro-social behavior.

\section{DISCUSSION}

The prevalence of children with an affected quality of life in this study reached $36.4 \%$, which shows that poor school performance may have a negative impact on quality of life. The international literature has shown similar findings, in which health-related quality of life was significantly impaired in children recently diagnosed with learning difficulties ${ }^{18,19}$.
Two Greek studies evaluated the quality of life of children using the KINDL instrument. In the first study, 116 children with a diagnosis of learning disability were evaluated (average age 10.7 years) and impairment in the emotional well-being, low self-esteem and deficits in their relationships with family and friends and in physical functioning was observed ${ }^{20}$. The other study compared children with and without learning disabilities and found that children with a learning disability showed poorer emotional well-being and low self-esteem ${ }^{21}$. Another study also concluded that children with learning difficulties showed a significantly lower self-concept than children without learning disabilities ${ }^{22}$.

In the literature, studies of children with poor school performance, that used the same assessment instrument as the present research, were not found. However, the AUQEI has been used to investigate the quality of life in other child populations and it was found that the prevalence of affected quality of life in children with leukemia was $15 \%{ }^{23}, 25 \%$ in children with cystic fibrosis ${ }^{24}$ and $33.5 \%$ in children with dermatoses ${ }^{25}$. These findings show that the same instrument was capable of measuring the quality of life in different situations. In this study, especially when compared to the others, the questionnaire showed a high prevalence of impaired quality of life in children with poor school performance.

It is believed that the pathologies with evident organic impairment may have the individual value the elements that make up the quality of life concept better. That is likely to be the reason for such differences in prevalence, as poor school performance does not always produce physiological symptoms and/or change in daily routines. The literature points

Table 3. Descriptive analysis and univariate association between quality of life and hearing processing tests.

\begin{tabular}{|c|c|c|c|c|}
\hline Variable & Not impaired n (\%) & Impaired n (\%) & Odds Ratio (95\% Cl*) & $\mathrm{p}$-value \\
\hline \multicolumn{5}{|l|}{ NVSMT } \\
\hline Adequate & $30(52.6)$ & 18 (56.3) & 1 & \\
\hline Inadequate & $27(47.4)$ & $14(43.7)$ & $0.86(0.36-2.07)$ & 0.74 \\
\hline \multicolumn{5}{|l|}{ VSMT } \\
\hline Adequate & $40(70.2)$ & $16(51.6)$ & 1 & \\
\hline Inadequate & $17(29.8)$ & $15(48.4)$ & $2.20(0.88-5.47)$ & 0.09 \\
\hline \multicolumn{5}{|c|}{ Sound localization test } \\
\hline Adequate & $53(93.0)$ & $31(96.9)$ & 1 & \\
\hline Inadequate & $4(7.0)$ & $1(3.1)$ & $0.42(0.45-4.04)$ & 0.46 \\
\hline \multicolumn{5}{|c|}{ Duration pattern test (Flute) } \\
\hline Adequate & $10(37.0)$ & $8(44.0)$ & 1 & \\
\hline Inadequate & $17(63.0)$ & $10(56.0)$ & $0.73(0.21-2.51)$ & 0.62 \\
\hline \multicolumn{5}{|l|}{ RGDT } \\
\hline Adequate & $11(22.0)$ & $5(19.3)$ & 1 & \\
\hline Inadequate & $39(78.0)$ & $21(80.7)$ & $1.18(0.36-3.89)$ & 0.78 \\
\hline \multicolumn{5}{|c|}{ Dichotic digits, RE } \\
\hline Adequate & $3(4.7)$ & $0(0.00)$ & - & - \\
\hline Inadequate & $54(85.7)$ & $32(88.9)$ & & \\
\hline \multicolumn{5}{|c|}{ Dichotic digits, LE } \\
\hline Adequate & $2(3.1)$ & $1(2.8)$ & 1 & \\
\hline Inadequate & $55(87.3)$ & $31(86.2)$ & $1.12(0.96-13.10)$ & 0.92 \\
\hline
\end{tabular}


to auditory processing disorders and behavioral manifestations, such as behavioral problems and emotional symptoms, as comorbidities related to poor school performance ${ }^{26,27}$. Moreover, hyperactive and inattentive children may be subject to quality of life impairments ${ }^{28}$. This study found a high number of children with behavioral and hearing alterations among the students who reported impairment in quality of life, although no statistical significance was found.

In a systematic review, Murray et al. ${ }^{26}$ concluded that Brazilian children show high rates of behavioral problems compared with children of developed countries. Furthermore, the authors identified that failing at school is a risk factor to behavioral problems in Brazil ${ }^{26}$. It is important to mention that changes in these areas may have an effect on the students without severe disabilities and, as evidenced by this research, there is a negative impact in quality of life in these children.

During the learning process, information processing depends on the integration of several abilities, highlighting cognitive, attentional, mnemonic and linguistic skills, not to mention emotional and behavioral development. Failures in this process cannot be attributed to a single cause ${ }^{29}$. Although the difficulties are present in the child, they can only be understood when considering different variables involved in the learning process.

In the final model (Table 5), the lack of the legal guardian's complaints about written language and the child's altered pro-social behavior were the variables that showed a statistically significant correlation with quality of life.

Table 4. Descriptive analysis and univariate association between quality of life, behavioral aspects, self-reported health status, and school life.

\begin{tabular}{|c|c|c|c|c|}
\hline Variable & $\begin{array}{c}\text { Not impaired } \\
\mathrm{N}(\%)\end{array}$ & $\begin{array}{c}\text { Impaired } \\
\mathrm{N}(\%)\end{array}$ & Odds Ratio $(95 \% \mathrm{Cl}$ ) & $p$-value \\
\hline \multicolumn{5}{|l|}{ Emotional symptoms } \\
\hline Normal & $22(35.5)$ & $8(22.2)$ & 1 & \\
\hline Altered & $40(64.5)$ & $28(77.8)$ & $1.92(0.74-4.96)$ & 0.17 \\
\hline \multicolumn{5}{|l|}{ Behavioral problems } \\
\hline Normal & $22(35.5)$ & $14(38.9)$ & 1 & \\
\hline Altered & $40(64.5)$ & $22(61.1)$ & $0.86(0.36-2.02)$ & 0.74 \\
\hline \multicolumn{5}{|l|}{ Hyperactivity symptoms } \\
\hline Normal & $30(48.4)$ & $14(38.9)$ & 1 & \\
\hline Altered & $32(51.6)$ & $22(61.1)$ & $1.47(.63-3.40)$ & 0.37 \\
\hline \multicolumn{5}{|l|}{ Problems with classmates } \\
\hline Normal & $32(51.6)$ & $12(33.3)$ & 1 & \\
\hline Altered & $30(48.4)$ & $24(66.7)$ & $2.13(0.94-5.03)$ & 0.08 \\
\hline \multicolumn{5}{|l|}{ Pro-social behavior } \\
\hline Normal & $57(92.0)$ & $28(77.7)$ & 1 & \\
\hline Altered & $5(8.0)$ & $8(22.3)$ & $3.25(0.96-10.94)$ & 0.06 \\
\hline \multicolumn{5}{|l|}{ SDQ total score } \\
\hline Normal & $21(33.9)$ & $10(27.8)$ & 1 & \\
\hline Altered & $41(66.1)$ & $26(72.2)$ & $1.33(0.53-3.28)$ & 0.53 \\
\hline \multicolumn{5}{|l|}{ Impact supplement of SDQ } \\
\hline Adequate & $17(27.9)$ & $8(22.9)$ & 1 & \\
\hline Inadequate & $44(72.1)$ & $27(77.1)$ & & 0.59 \\
\hline \multicolumn{5}{|c|}{ Parental report of child's health status } \\
\hline Very good & $7(11.3)$ & $5(13.9)$ & & \\
\hline Good & $45(72.6)$ & $28(77.8)$ & $0.87(0.25-3.03)$ & 0.83 \\
\hline Fair/bad/very bad & $10(16.1)$ & $3(8.3)$ & $0.42(0.74-2.38)$ & 0.33 \\
\hline \multicolumn{5}{|c|}{ Children's self-reported health status } \\
\hline Very good & $20(31.8)$ & $10(27.8)$ & & \\
\hline Good & $30(47.6)$ & $12(33.3)$ & $0.80(0.28-2.21)$ & 0.67 \\
\hline Fair/bad/very bad & $13(20.6)$ & $14(38.9)$ & $2.15(0.73-6.31)$ & 0.16 \\
\hline \multicolumn{5}{|l|}{ Flunking } \\
\hline No & $51(83.6)$ & $23(65.7)$ & & \\
\hline Yes & $10(16.4)$ & $12(34.3)$ & $2.66(1.00-7.07)$ & $0.05^{* *}$ \\
\hline \multicolumn{5}{|l|}{ School enjoyment } \\
\hline Yes & $42(66.7)$ & $19(52.7)$ & & \\
\hline No & $20(31.7)$ & $17(47.3)$ & $1.87(0.80-4.38)$ & 0.14 \\
\hline \multicolumn{5}{|c|}{ Complaints about written language } \\
\hline Yes & $47(75.8)$ & $21(58.3)$ & & \\
\hline No & $15(24.2)$ & $15(41.6)$ & $2.23(0.92-5.42)$ & 0.07 \\
\hline
\end{tabular}


Table 5. Multivariate analysis final model

\begin{tabular}{|c|c|c|c|}
\hline Variable & Odds ratio & $\mathrm{Cl}^{*}(95 \%)$ & $\mathrm{p}$-value \\
\hline \multicolumn{4}{|c|}{ Complaints about written language } \\
\hline Yes & & 1 & \\
\hline No & 2.92 & $1.15-7.39$ & $0.02^{* *}$ \\
\hline \multicolumn{4}{|c|}{ Pro-social behavior } \\
\hline Normal & & 1 & \\
\hline Altered & 4.55 & $1.30-15.87$ & $0.02^{* \star}$ \\
\hline
\end{tabular}

It is fundamental to value the family and caregiver perspective regarding children, especially when there are complaints about child development. In this research, when the parents did not notice the changes in written language development, children were 2.92 times more likely to experience an affected quality of life compared with those whose parents did complain about written language. Therefore, a possible hypothesis is that having parental recognition and participation in school matters and academic development influences the child's perception of quality of life. It should be pointed out that parents and children do not always have the same perception of quality of life ${ }^{20}$.

The altered pro-social behavior increased the odds of having an affected quality of life by 4.55 times when compared with children who have proper behavior. The data are corroborated by the literature that emphasizes that the quality indicators of relationships maintained in the school context show an association with performance in reading and writing, which highlights the importance of the so-called academic social skills for school learning ${ }^{10}$.

From these findings, it can be assumed that behavioral matters are more often noticed by parents than the more specific complaints about school issues.

Obviously, it is limiting to assess exclusively by quantification, a concept intrinsically marked by subjectivity, such as the quality of life construct, especially in a population of children. The association of quality of life related by children and parents could offer more information about this. Moreover, because this was a transversal study, it was not possible to establish the causal relationship between quality of life and the investigated factors. It should be emphasized that there are still few studies to date that assess quality of life and poor school performance, which made it difficult to compare the results.

As a conclusion, a high prevalence of affected quality of life in children with poor school performance has been identified. The negative impact on the quality of life of these children was related to altered pro-social behavior and the absence of parental discontent about the development of written language. These findings are extremely important to establish a relationship among quality of life, behavioral aspects and poor school performance and may help with support for planning actions involving the child's quality of life.

\section{References}

1. Dowd AJ, Friedlander E, Jonason C, Leer J, Sorensen LZ, Guajardo $\mathrm{J}$ et al. Lifewide Learning for Early Reading Development. New Dir Child Adolesc Dev. 2017 Mar;2017(155):31-49. https://doi.org/10.1002/cad.20193

2. American Psychiatric Association. Manual diagnóstico e estatístico de transtornos mentais. DSM-5. 5a ed. Porto Alegre: Art Med; 2014.

3. Siqueira CM, Gurgel-Giannetti J. [Poor school performance: an updated review]. Rev Assoc Med Bras (1992). 2011 JanFeb;57(1):78-87. Portuguese.

4. Minayo MC, Hartz ZM, Buss PM. [Quality of life and health: a necessary debate]. Cien Saude Colet. 2000;5(1):7-18. Portuguese. https://doi.org/10.1590/S1413-81232000000100002

5. WHOQOL Group. The World Health Organization Quality of Life assessment (WHOQOL): position paper from the World Health Organization. Soc Sci Med. 1995 Nov;41(10):1403-9. https://doi.org/10.1016/0277-9536(95)00112-K

6. Assumpção Junior FB, Kuczynski E, Sprovieri MH, Aranha EM. [Quality of life evaluation scale (AUQEI): validity and reliability of a quality of life scale for children from 4 to 12 years-old]. Arq Neuropsiquiatr. 2000 Mar;58(1):119-27. Portuguese. https://doi.org/10.1590/S0004-282X2000000100018

7. Pereira LD, Cavadas M. Processamento auditivo central. In: Frota S, editor. Fundamentos em audiologia. 2a ed. Rio de Janeiro: Guanabara-Koogan; 2003. p. 141-56.

8. Oliveira AM, Cardoso AC, Capellini SA. [Performance of students with learning disabilities and dyslexia on auditory processing tests]. Rev CEFAC. 2011;13(3):513-21. Portuguese. https://doi.org/10.1590/S1516-18462010005000126
9. Gardinal EC, Marturano EM. [Boys and girls in kindergarten: association between behavior and achievement]. Psicol Estud. 2007;12(3):541-51. Portuguese. https://doi.org/10.1590/S1413-73722007000300011

10. D’Abreu LC, Marturano EM. [Association between externalizing behavior and underachievement: a review of prospective and longitudinal studies]. Estud Psicol. 2010;15(1):43-51. Portuguese. https://doi.org/10.1590/S1413-294X2010000100006

11. Ministério da Educação (BR). Resolução CNE/CBE N4, de 2 de outubro de 2009. Institui Diretrizes Operacionais para o Atendimento Educacional Especializado na Educação Básica, modalidade Educação Especial. Brasília, DF: Ministério da Saúde; 2009 [cited 2014 Apr 06]. Available from: http://portal.mec.gov.br/index. php?catid=323: orgaos-vinculados\&id=13684: resolucoes-ceb009\&option=com_content $\&$ view=article

12. Associação Brasileira de Empresas de Pesquisa - ABEP. Critério de Classificação Econômica Brasil. São Paulo: Associação Brasileira de Empresas de Pesquisa; 2008 [cited 2013 May 26]. Available from: http://www.abep.org/novo/Content.aspx?SectionID=84

13. Goodman R, Meltzer H, Bailey V. The strengths and difficulties questionnaire: A pilot study on the validity of the self-report version. Eur Child Adolesc Psychiatry.1998 Oct;7(3):125-30. http://doi.org/10.1007/s007870050057

14. Pereira LD, Schochat E. Testes auditivos comportamentais para avaliação do processamento auditivo central. São Paulo: Pró- Fono; 2011.

15. Amaral MI, Martins PM, Collela-Santos MF. Temporal resolution: assessment procedures and parameters for school-aged children. Rev Bras Otorrinolaringol. 2013 May-Jun;79(3):317-24. https://doi.org/10.5935/1808-8694.20130057 
16. Associação Brasileira de Normas Técnicas - ABNT. NBR 10151. Acústica: Avaliação do ruído em áreas habitadas, visando o conforto da comunidade - procedimento. Rio de Janeiro: Associação Brasileira de Normas Técnicas; 2000.

17. Associação Brasileira de Normas Técnicas - ABNT. NBR 10152: Niveis de ruído para conforto acústico. Rio de Janeiro: Associação Brasileira de Normas Técnicas; 1987.

18. Karande S, Venkataraman R. Self-perceived health-related quality of life of Indian children with specific learning disability. J Postgrad Med. 2012 Oct-Dec;58(4):246-54. https://doi.org/10.4103/0022-3859.105442

19. Karande S, Bhosrekar K, Kulkarni M, Thakker A. Healthrelated quality of life of children with newly diagnosed specific learning disability. J Trop Pediatr. 2009 Jun;55(3):160-9. https://doi.org/10.1093/tropej/fmn099

20. Rotsika V, Coccossis M, Vlassopoulos M, Papaeleftheriou E, Sakellariou K, Anagnostopoulos DC, et al. Does the subjective quality of life of children with specific learning disabilities (SpLD) agree with their parents' proxy reports? Qual Life Res. 2011 Oct;20(8):1271-8. https://doi.org/10.1007/s11136-011-9857-z

21. Ginieri-Coccossis M, Rotsika V, Skevington S, Papaevangelou S, Malliori M, Tomaras V, et al. Quality of life in newly diagnosed children with specific learning disabilities (SpLD) and differences from typically developing children: a study of child and parent reports. Child Care Health Dev. 2013 Jul;39(4):581-91. https://doi.org/10.1111/j.1365-2214.2012.01369.x

22. Stevanato IS, Loureiro SR, Linhares MB, Marturano EM. Autoconceito de crianças com dificuldades de aprendizagem e problemas de comportamento. Psicol Estud. 2003;8(1):67-76. https://doi.org/10.1590/S1413-73722003000100009

23. Sommerfeld CE, Calmon CM, Sperandio F, Machado A, Beltrame T. Qualidade de vida de crianças em tratamento clínico de leucemia. Brasília Med. 2011;48(2):129-37.

24. Pfeifer LI, Silva MA. Avaliação da qualidade de vida em crianças com fibrose cística. Rev NUFEN. 2009;2(1):118-30.

25. Weber MB, Lorenzini D, Reinehr CP, Lovato B. Assessment of the quality of life of pediatric patients at a center of excellence in dermatology in southern Brazil. An Bras Dermatol. 2012 Sep-Oct;87(5):697-702 https://doi.org/10.1590/S0365-05962012000500004

26. Murray J, Anselmi L, Gallo EA, Fleitlich-Bilyk B, Bordin IA. Epidemiology of childhood conduct problems in Brazil: systematic review and meta-analysis. Soc Psychiatry Psychiatr Epidemiol. 2013 Oct;48(10):1527-38. https://doi.org/10.1007/s00127-013-0695-x

27. Oliveira JC, Murphy CFB, Schochat E. Processamento auditivo (central) em crianças com dislexia: avaliação comportamental e eletrofisiológica. CoDAS. 2013;25(1):39-44. https://doi.org/10.1590/S2317-17822013000100008

28. Danckaerts M, Sonuga-Barke EJ, Banaschewski T, Buitelaar J, Döpfner M, Hollis C, et al. The quality of life of children with attention deficit/hyperactivity disorder: a systematic review. Eur Child Adolesc Psychiatry. 2010 Feb;19(2):83-105. https://doi.org/10.1007/s00787-009-0046-3

29. Rotta NT, Ohlweiler L, Riesgo RS. Transtornos da aprendizagem: abordagem neurobiológica e multidisciplinar. Porto Alegre: Armed; 2006. 